\author{
“Art Investment Collections: \\ A New Model for Museum Finance?” \\ Erica Coslor \\ University of Chicago, Department of Sociology \\ 1126 East 59th Street, Chicago, IL 60637 \\ ecoslor@uchicago.edu
}

\title{
07-17-09 Version
}

\begin{abstract}
This article examines the conflicting views about whether to consider artwork as a financial asset and suggests a modified museum finance strategy that would not raise stakeholder concerns about selling art in the permanent collection. By encouraging museums to begin a separate investment collection, artworks may ethically be sold to generate operating or other expenses. This strategy brings up issues of governance, accountability, and conflicts of interest, but if done correctly, it could leverage the art market access of museums to create a hedge for other types of endowment assets, while still upholding museum association guidance that works in a museum's permanent collection are never to be sold in order to fund operating expenses. (114 words)
\end{abstract}

\section{KEYWORDS}

Museum finance, art as an investment, university museums, deaccessioning, investment collections

DRAFT VERSION, PLEASE DO NOT QUOTE OR CITE WITHOUT MY PERMISSION 


\section{Introduction}

In the late 1800s, steel baron Henry Clay Frick noted that "some paintings were seen to increase sometimes a hundred, thousand fold more rapidly than the certificates of the best-managed joint stock companies” (Chancellor 2000). Although artwork has always been an object that possessed monetary value, it is primarily in the last forty years that artwork has come to be seen as a financial asset, and only in the last few years has it become accepted by financial managers (Willette 2009). The financial interest is often generated by the high auction prices and stories of huge financial returns that are common in the art world, in addition to newer advice about portfolio diversification.

This investment framing may be logical for collectors, who can consider their art holdings as part of a financial investment diversification strategy, in addition to the aesthetic benefits of owning art. Most people would also agree that art is a good with both cultural and financial investment qualities. For museums, the issues are more complex. Some museums and researchers have lobbied for the ‘capitalization' of permanent collections, and the recent financial crisis has spurred some museums to sell off paintings or full collections, or have been forced to do so by a parent university. However, deaccessioning to pay for operating costs is against museum association ethical guidelines, ${ }^{1}$ as well as the mission of museums to hold artwork in the public trust. Using case studies and previous research, I would like to highlight the active debate about the contexts in which art's investment potential should be given priority. Controversies around events like the surreptitious deaccessions of four paintings from the Maier Museum of Art at Randolph College in Lynchburg, Virginia (Katzman and Lawson 2009) and threatened closure of Brandeis’ Rose Museum (Finkel 2008) show that many people have strong views about the intended uses of artwork held in museums. These problems could be framed as a 
tradeoff between profiting financially from artwork and eroding stakeholder trust in the institution. Thus, if museums treat artwork too much like a financial asset, with all the attendant liquidity, ease of sale and commensurability, this could create long term negative repercussions for potential patrons and donors, who are likely to lose faith in the institution, which can translate into reduced donations of art or money. ${ }^{2}$ This article suggests that while art possesses both cultural and monetary value, and can be successfully used for financial investment diversification in some contexts, it is important for cultural institutions to carefully consider the implications of increasing the investment focus, which can have both positive and negative consequences.

The recent financial crisis and attendant endowment declines have increased pressure on some museums to find cost savings and new revenue sources wherever they can, particularly in universities with museums, and those museums where endowments and donations have been used to finance a large portion of operating costs. In this context, but also at various points in the past, museums have seen some board members and other stakeholders argue that selling off some works from the permanent collection would be a good way to raise needed revenues. But while the sale of one or two works can bring several million dollars of needed relief to a museum facing a funding gap, this practice is expressly prohibited by the ethical codes of the American Association of Museums (AAM) and the American Association of Museum Directors (AAMD). While it is not technically illegal for museums to sell works in order to fund operating expenses, so long as that is consistent with the original terms for works that were donated (Finkel 2008), the ethical guidelines of the two associations only allow sales whose revenues are used to purchase new works, and sanctions are typically levied against member institutions that break these ethical rules. ${ }^{3}$ 
While some cultural policy researchers suggest that museums should change the deaccessioning guidance to allow sales in times of need (e.g. O'Hare 2005), museums could productively incorporate the idea of an investment collection in a way that balances the conflicting pressures of financial considerations and current ethical concerns about sales. ${ }^{4}$ Such a collection would be held separately from the permanent collection, effectively as part of the endowment, and works from this investment collection-and no other-would be able to be sold in order to finance operating costs, capital projects or other expenses. This collection could also be a place for supporters of the museum to donate lesser quality works designated for resale to benefit the museum. Such plans could help to reconcile what is actually a wider public debate about the cultural vs. monetary aspects of art, and revalorize the view that while all works of art can theoretically be treated as financial assets, only some works of art (i.e. the investment collection) will ever be treated as such by the museums. Without such a decisive stance, museums will continue to face strong pressure from financially-minded board members and others to treat artwork in the permanent collection as potential financial assets that can be converted into cash, whether this is only done in times of extreme need, or at will, the way a business would sell off excess buildings or equipment. ${ }^{5}$ This is because different people hold strong and divergent views about whether art is or should be considered a financial asset.

The rest of the article is divided into three main sections. I first outline the typical museum finance strategies, discuss the impact of economic downturns, and talk briefly about endowments and endowment law. Next I turn to the core theory about why deaccessioning creates such controversies, by considering the art as investment view versus the museums as cultural conservators view, highlighting the dual nature of art and the diversity of views around art as a financial category, with evidence from ethnographic research and case studies. Section 
three summarizes research in cultural economics on artwork as an investment category. Finally, I offer four different solutions to the tradeoff between the financial attributes of art and the erosion of stakeholder trust caused by deaccessions, using different forms of an investment collection, with discussion of tax implications, accountability and conflicts of interest.

Making the distinction between an investment collection and a permanent collection is a realistic way for museums to develop a clear position in the ongoing debate about how to categorize artwork. Such a division will give donors, museum staff and other stakeholders peace of mind that the permanent collection will not be treated as a financial asset in times of need. Finally, given the portfolio diversification aspects of artwork as an asset, the inclusion of various works into the endowment portfolio could help to hedge against the problems of widespread stock market downturns as we have seen today. Regardless of whether an art investment strategy is pursued, this research should inform a wider discussion about the advantages and disadvantages that are likely to be faced if a cultural institution treats artwork as a financial asset.

\section{Museum Finance Strategies}

Museums are typically financed by a variety of different revenue streams, but because museum attendance and charity donations are discretionary expenses for patrons, the composition of these revenue sources means that in good economic times there is a multiplier effect to increase revenues and in times of economic downturn, this turns into a negative multiplier effect. This means museums must have careful budgeting. While the variable expenses of museums, such as the purchase of artwork and some operating expenses, can be reduced in hard times, for example cutting back on staff, other costs are fixed and difficult to change, for example, ongoing bond payments for previous building expansions. For these reasons, the composition of revenue can exacerbate economic volatility. 
Museums are typically funded by a mixture of four sources, although not necessarily in this order: 1) Donations and other gifts; 2) Admissions revenues; 3) Related businesses, such as museum cafes and gift shops; and 4) Endowment earnings. Notably missing from these categories are what some board members and academic researchers (e.g. O'Hare 2005) would also consider to be revenue sources for the museum, namely the artwork and artifacts. The following table lists the average percentages across the sample of museums surveyed by the American Association of Museums (AAM) in 2005, where we can see decreasing government support and increasing private support.

\section{[INSERT TABLE 1 HERE]}

In an economic downturn, donations, admissions, and related business earnings are all likely to decrease, as wealthy patrons cut back on charitable giving and families cut back on discretionary expenses like travel or museum visits, which also tends to decrease the related business earnings income for museums. Another point to note is the fact that some museums use endowment earnings to fund a good portion of ongoing operating expenses, so the investment strategy of the endowment is a key factor in ensuring the continued financial sustainability of these museums.

\section{Endowments}

Many large museums rely on endowment revenues to help fund operating income, but this has created problems recently with the stock market downturn, given that most endowments are invested in a mixture of equities such as stocks, bonds, and index funds. The current financial crisis means that endowment revenues have suffered, as an example, the Metropolitan Museum of Art's endowment has lost about $25 \%$ of its value since July 2008, and endowment income was used for about 30\% of the museum's operating expenditures (Houghton 2009). Endowment 
losses at other well-endowed museums have also been large. The Los Angeles Getty Museum has had the highest endowment of all U.S. museums, and its portfolio dropped 25\%, from $\$ 6$ billion to $\$ 4.5$ billion, during the last half of 2008 (Boehm 2009).

At the same time, these two cases are at the extreme, and perhaps more indicative of the problems of major museums with large endowments. The AAM survey found that although $61 \%$ of the museums who responded had endowments with a median value of $\$ 1.6$ million, these revenues only generate a median value of 5 percent of operating income (Kolter, Kolter and Kolter 2008, 192). However, even if a museum does not have a large endowment, stock market losses can be harmful, because many endowments are locked up law if the values drop below a certain value (Gallagher 2009). ${ }^{6}$

\section{Art Assets vs. Stakeholder Trust}

Before laying out the financial investment justifications of treating art as an asset, it is important to discuss the problems with this view, because an improperly executed strategy could have negative effects such as harm to stakeholder relations, reduced trust in the institution, decreased donations of money or artwork, and other types of harm. There are two distinct of problems with viewing art as an asset, pragmatic problems of valuation, storage and returns, which are typically problems for the financial practitioner and cultural economist, and public or moral concerns about whether art should be considered as an asset. ${ }^{7}$ An extension of this view is that artwork in museums is meant to be held in the public trust, for posterity, and thus cannot be categorized as a financial asset.

The ethical rules for museum deaccessions given by the AAM and AAMD are motivated by a certain view of how to categorize artwork in public and nonprofit collections, one that sees artwork as incommensurable with money. In this view, artwork is seen as a legacy of cultural 
heritage and ideally should never be sold. Careful sales are allowed in order to refocus a museum's collections, but the proceeds of these deaccessions are only to be used to purchase new artwork. The competing view is that artwork is a type of financial asset, much like property, and it can be converted to money with no loss of its cultural value, and should be considered as a financial resource when other funding sources are low. ${ }^{8}$ This business logic often comes in when business executives become trustees and board members of a museum. Graham Beal, director of the Detroit Institute of Arts, said he often gets questions from new trustees about selling artworks, who ask questions like “Since we have four van Goghs, people say why don’t we sell one of the van Goghs?” when they take their knowledge of business into the museum setting. Interpreting this view, Beal pointed out that "[i]t makes perfect sense in the business world, where they're looking for assets to sell the way Ford sold Jaguar” (quoted in Finkel 2008). In this second view, artworks are assets of the institution that can be gained or disposed of at will, and should be used to support other functions of the organization, a perfectly reasonable view in business, but one that conflicts with the fungibility norms of the art world. While these two views — the art world and the business logic—are ideal types and the viewpoints of actual people are likely to vary, my typology does make it clear why there would be a conflict in whether to view artworks as financial assets that can be disposed of as a profit, particularly in the context of successful executives joining museum boards.

With this distinction in mind, the conflict underlying deaccession should be more clear, and it should also be noted that this conflict precedes the current endowment problems. "Even before the economic downturn, however, museums had been finding ways around AAMD in a power struggle between directors and trustees, who want to unlock the value of their collections, 
and the museum-going public, which feels betrayed by the institutions that are designed to preserve and honor donations” (Panero 2009).

Given that public perceptions of art as an asset vary, and for some people, treating art in a museum as a fungible profit source is value destroying, there is a tradeoff at work. This distinction can be roughly characterized in the following chart, a hypothetical model of tradeoffs for a museum, based on a modified production possibility frontier. This helps to make clear the tradeoffs posed by treating artwork as a liquid, saleable asset by the museum, in terms of stakeholder trust in the institution, and trust would relate to whether stakeholders would be willing to donate money, artwork or other forms of patronage. At present, most museums would fall in the upper left quadrant, such as around point A, where artworks (as assets) are only sold infrequently, and according to strict guidelines, which helps to engender higher stakeholder confidence, particularly that of potential donors of artwork. Business-minded trustees are trying to push toward point B, or farther down, meaning that there is a higher degree of liquidity among the art assets, but likely a tradeoff in terms of stakeholder trust, as donors begin to fear whether their treasured gifts might be sold off for profits in the future. 


\section{Figure 1: A Production Possibility Function for Museums}

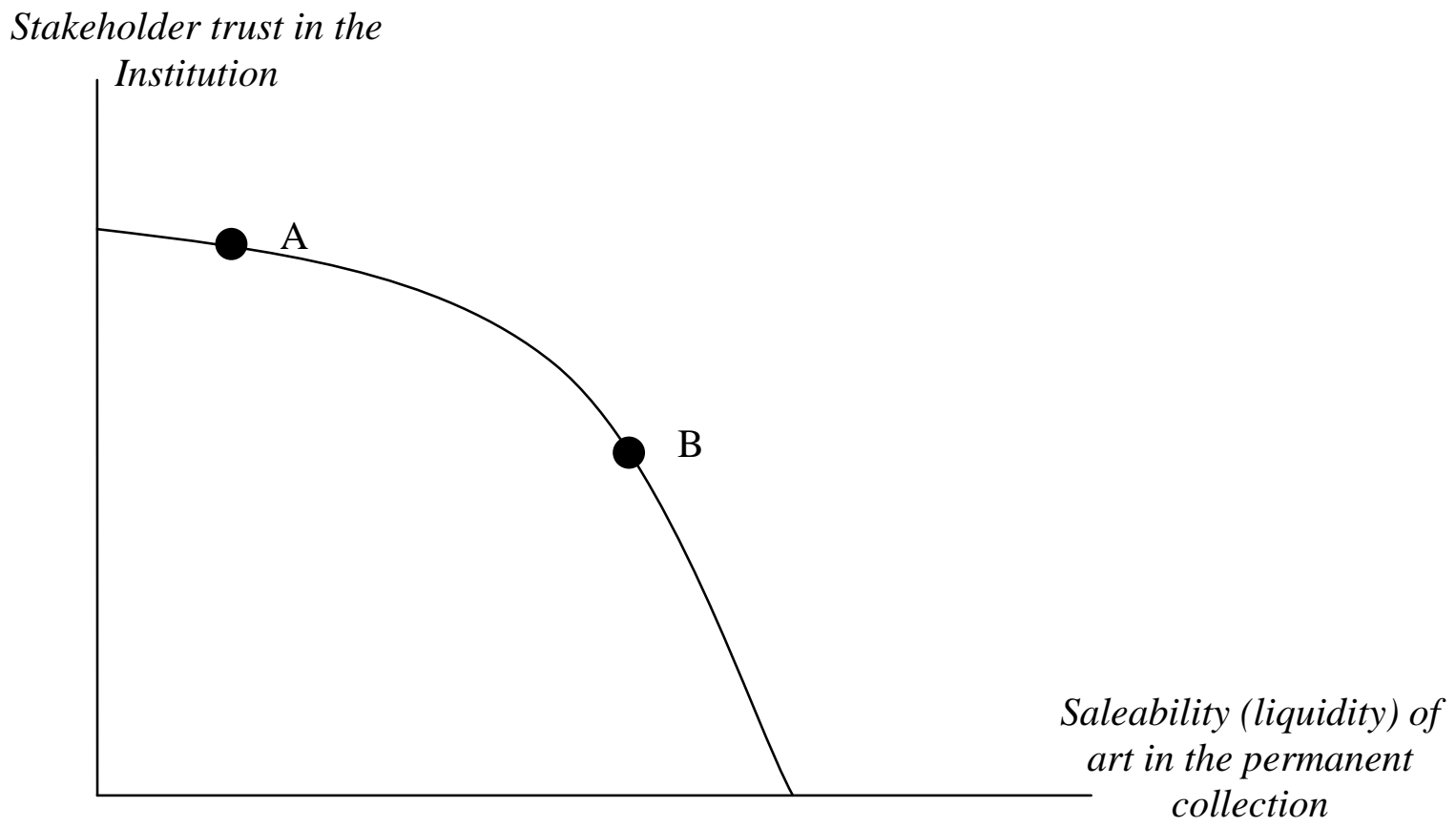

While the efforts of academics and practitioners in the area of art investment have done enough work to convince most financial managers that art is indeed a potential asset class (Willette 2009), ${ }^{9}$ standing alongside other alternative assets like hedge funds, this shifting of classification is as yet an unsolved problem for many people, particularly for art in museum collections. The various, strongly held views about recognizing the monetary and investment aspects of artwork are an acute conflict in part because those on different sides of the debate are expressing different ethical considerations, from a pragmatic focus on the continued operation of an organization, to the role of protecting precious cultural assets, and so forth. These debates about the investment status of art echo other research on the status of art, such as artwork as an elite status good vs. a group identity good or socially inclusive good (Kidd 2009). 


\section{DEACCESSIONING CONCERNS \& PRACTICES}

The practice of deaccessioning artwork, or selling it off, is usually understood by museum staff to be fairly controversial, and most museums carefully deaccession works according to a strict set of guidelines and in ways that relate to the museum's mission. In the U.S., AAM and AAMD ethical guidelines prohibit museums from selling works, except when the proceeds of these sales are used for the purpose of buying more art. Over time, these guidelines have increasingly met challenges, and museums who are not members of the AAM or AAMD are not bound by those rules. ${ }^{10}$ From the perspective of museum directors, there is also a concern about deaccessioning creating an unpleasant precedent. Director Graham Beal, mentioned before, worried that "[i]f it were suddenly legitimate to sell artworks and use the proceeds for anything other than acquisitions... there would be a wholesale cannibalization of many museums” (Finkel 2008).

Not everyone is a fan of the museum association rules, but for varying reasons. Some feel that it would be in the public good to distribute artworks more widely than in just a few museums (O'Hare 2005). Lawyer Donn Zaretsky argues that the AAMD guidelines that allow museums to sell work for the purposes of further acquisitions mean that the works are not held in public trust, as intended, and suggests that the nature of holding works "in the public trust" should mean that the rules would allow sales between different institutions (Zaretsky 2009), although it should be pointed out that this could conflict with the specific donor wishes that guide endowment and donation laws. Despite criticisms of the museum ethical guidelines, the outright sale of artwork by museums tends to stir up public controversies, and the damage in stakeholder confidence with using art as an asset is most clearly illustrated by deaccessioning controversies. 


\section{DEACCESSIONING CONTROVERSIES}

Deaccessioning is a hot-button issue for the general public, and the most recent example is the massive public outcry around the threatened closure of Brandeis University’s Rose Museum. As opposed to the type of by-the-books deaccessions endorsed by the AAM and AAMD, unrestricted sales of paintings from the permanent collections of museums tend to become public, particularly when there are attempts to do these sales surreptitiously, or when they are carried out by parties who ignore or are unfamiliar with the intent of the museum association ethical guidelines.

The Rose Museum is a good example to study the harms wrought by inappropriate deaccessions. Facing a budget shortage, Brandeis University started to look at the possibility of selling off artworks from the museum, and in January 2009, announced that it would close the museum and sell nearly 6,000 pieces from its collection in order to offset the school's estimated $\$ 10$ million budget deficit (Johnson 2009). The sale of some works from the art collection was to finance the massive gaps in the university's operating budget, which were caused by investment losses from the financial crisis coupled with losses suffered by key university donors who had invested with Bernie Madoff (Wee and Lorin 2009). This brought on a huge storm of public criticism. In response, the university decided to close the museum in its current form and reopen it as a teaching institution, however, the damage has been done. This entails reputational damage for both the university and the museum specifically. Donor trust in the museum has plummeted, for example, according to Meryl Rose, a member of the Rose's Board of Overseers and a relative of the original founders of the museum, “There was a \$2 million dollar gift, and the person who gave it is asking for it back - it was someone who had given a great deal in the past” (quoted in

Johnson 2009). Although this case is still unfolding, with the president indicating that only a few 
works would be sold after all (Zaretsky 2009) it indicates the types of harms caused by deaccessioning to help fund a parent university. A sampling of commentary about the Brandeis Rose Museum quickly reveals negative reactions from alumni and other donors who have completely lost faith in the university, therefore what was hoped to be a financial quick-fix turned into an event with much wider negative publicity.

University museum deaccessions are perhaps a special category for this type of controversy, because in these cases the university does maintain some administrative control over the museum. However, some cases, like the Maier Museum of Art at Randolph College in Lynchburg, Virginia, show particular neglect of museum association guidelines. In the case of the Maier Museum, college officials whisked away four key paintings for sale at auction, using a bomb threat to enforce a police cordon. The paintings were to be sold in order to increase the school's general operating endowment, and in response to an earlier financial warning by the accreditation authority, the Southern Association of Colleges and Schools (SACS) (Katzman and Lawson 2009). This is an extreme case, because the sales not only violated AAM ethical guidelines, but also the intent of the donors of the paintings, according to heirs of the original donors (Katzman and Lawson 2009), although this may also be the basis for a lawsuit over the Rose museum (Johnson 2009).

In another case of revenue shortfalls prompting deaccessioning, the National Academy Museum in New York sold off two paintings from the collection after an almost unanimous vote by its members. This was after a vote against selling off the museum's Fifth Avenue building, which left the museum with few options. While the private sale generated some \$15 million, it also earned a swift rebuke from the AAMD, which called upon members to suspend loans of work and refuse collaborative exhibitions (Zaretsky 2009). Despite the rebuke, director Carmine 
Branagan noted that the Academy was careful about this choice. "I remember saying [to the board]: 'Unless you believe you can support sweeping change, then do not vote for deaccessioning.' The tragedy isn't that we're going to sell these four pieces. That's not a tragedy. The tragedy would be if in 10 or 15 years we were back here having the same conversation” (quoted in Finkel 2008).

While the motives for most museum deaccessions that fund operating budget gaps are usually honorable, it is important to weigh short-term gains against potential losses, because such incidents impact a museum's reputation and thus the potential for future financial support and donations of artwork. For this reason, I have to agree with opponents of deaccessioning who suggest that improper deaccessioning can cause reputational damages or otherwise harms the institutions in question, due to the media frenzy that usually results from such incidents. Moreover, cases of this nature could set a distasteful precedent. Of the cases mentioned, only the National Academy decision was made in a cautious, evenhanded fashion, with consideration of the factors that brought the museum to this state. With the strongly divergent views about the financial potential of art in museums, along with deaccession controversies in mind, there are some key reasons why the financial investment community is interested in artwork.

\section{Art as an Asset}

The early example of modern, strategic investment in art is the British Rail Pension Fund (BRPF), and is often mentioned when I interview representatives from the art investment community. The fund was Britain's first (and it is believed only) large pension fund to enter the collectibles market at the time (Trucco 1989). British Rail invested $£ 40$ million, equivalent to $2 \%$ of its overall funds, and earned a reputation for being “one of Europe's greatest art patrons since the Medici” (Blake 2003). From 1974 to 1999, the fund invested in more than 2,400 works of art 
of various types, including Old Masters and Impressionist works, books, manuscripts, medieval art and sculpture, and Chinese ceramics (Baram 2005) to supplement more conventional investments and serve as a hedge against inflation, which was extremely high in Britain at the time (Trucco 1989). According to Susan Adeane, one of the directors of the art investment group during this time, their goal was to invest in something that would match or beat inflation, which was difficult at the time, because "the stock market had fallen very heavily, the property market had collapsed... we didn’t have index linked securities. ...there weren't the options of commodities or hedge funds or international bonds.” Even with foreign investments, there were limitations, "and to diversify overseas, there were exchange controls and a high dollar premium...” The view was that investing in art and antiques was a strategy that stood a very strong chance of at least matching inflation (Adeane 2008).

The returns varied by the type of art, but were encouraging: "over the whole [art] portfolio, it was a real rate of return of 4\% per annum, over the whole period... 1974 to 2003.” Ultimately it was selling off the holdings of Impressionist art at a time when that market was strong that made the ultimate returns of the fund higher All told, this meant that the investment in art was one that not only met, but exceeded the pension fund's expectations. "We used to describe it as a sort of sea anchor," says Adeane. British Rail's decision to realize the portfolio was made in 1987 for several reasons. "The art market was doing well at the time... there was a much wider choice of investments, even then, starting to become available... it was a bit uncertain whether the valuations of potential sales proceeds were keeping pace with inflation,” and finally, she notes that "much as I loved working with it, because it was great fun," administratively, it wasn't as easy as traditional forms of investment. While the art portfolio lacked high fund managers’ fees, it involved a lot of time and energy (Adeane 2008). ${ }^{11}$ 
The British Rail Pension Fund also faced various concerns around art investing, including moral concerns similar to those previously mentioned. According to Susan Adeane (2008), there was a little bit of adverse publicity, "first of all, because it was such an unusual thing for a pension fund... and it was unusual for the art market to have an institutional investor in it.” Moreover, the size of the fund raised fears that this activity could distort the art market, with the amount of money available to invest. Another concern, which eventually dissipated, involved the particular function of art as a cultural asset. The concern was that the fund would "buy all these treasures for the nation, and then put them in [storage] and then that would be it.” According to Adeane, they always had as much as possible out on loan, which served a number of strategic purposes. This policy was partly commercial, in showing the work, and also to highlight some of the cultural benefits of the collection being affiliated with the BRPF. Says Adeane, "we deliberately targeted some of the national institutions and... galleries in smaller towns which have big railway connections,” including York City Art Museum, York Art Gallery, and Doncaster museum.

Since the British Rail Pension Fund began buying artwork, other investment funds have bought works of art to include amongst their assets for the purposes of diversification. There are several different types of investors who are putting money into artwork, including individuals who directly make their own investment-type art purchases, firms that are buying art as a part of their investment portfolio, and dedicated art investment funds who have assets that are all works of art. In this last category, firms tend to use the closed-end private equity fund structure, and investors are often other funds or high net worth individuals who would like to diversify their assets. There have been a number of these funds, from the Fine Art Fund to the China Art Fund, 
to Meridian Art Partners, based in New York (Gerlis 2008). Out of these funds, however, the Fine Art Fund has established the strongest track record for investment.

\section{ART INVESTMENT RETURNS}

It is difficult to say what the predicted returns of art investment will be, because there are so many different market segments for artwork, and profits depend on the type of art, the initial acquisition price, holding costs such as storage and insurance, and various types of demand factors at the desired time of sale. Nevertheless, there is a whole area of research in cultural economics working to calculate the returns of artwork, particularly as compared to other types of financial assets like stocks and bonds. McAndrew (2007) provides a useful comparison of this work, and finds real rates of return varying from $0.21 \%$ for modern and contemporary Italian paintings (Candela and Scorcu 1997), all the way up to $48.2 \%$ for modern Chinese (Mok, Ko, Woo and Kwok 1993), with most figures at about 5\% real returns. The average returns compare to well above bond returns, but below average stock returns over time.

Despite these moderate returns, which are close to those of the British Rail Pension Fund, there is also a "gold rush" mentality prompted by both visible high art prices at auction and academic findings of extra normal returns that helps to explain the interest in art as an investment, coupled with the rationale for using art for portfolio diversification. Even conservative returns can be considered desirable for portfolio diversification strategies, with some research in this area finding that art is less correlated to traditional asset categories and is thus useful as a hedge (e.g. Campbell 2008). A further justification is that art buying has different tax implications, in part because it can be difficult to value artwork, and there may be also tax benefits for works bought in another country. However, the benefits and tax implications 
of using art as an investment will depend upon whether it is purchased by an investment fund, organization or individual.

\section{Museum Investment Collections}

In order to make recommendations about a possible art investment fund, I have included several options that may be appealing to various types of museums. Although these are not the only possible options, these four different ways of implementing an art investment collection enable better comparisons of the potential advantages and disadvantages of such plans. This should be treated as a long-term investment (Watson 1992, 428-30), as the ideal holding period for artwork is usually given at 10-19 years, with some suggesting 20-30 years (e.g. Robertson 2005, 248). This long timeframe is usually necessary to realize the capital appreciation necessary for profits, given that artwork does not provide monetary dividends, and entails storage and insurance costs, as well as high transaction costs to buy and sell. Additionally, most advice suggests that artwork

should only a small part of the overall endowment portfolio; even in the case of the successful art buying by the British Rail Pension Fund, no more than 3\% of the pension funds were invested in art and antiques (Adeane 2008).

The first two strategies are more conservative plans based on outside management and advising, and may be more appropriate for large museums. The third and fourth plans require the museum to handle active management of the investment portfolio, and provide two different areas of focus, an internal investment collection that can include donations from museum patrons, and a young artist development collection, which may appeal more to curators and museums concerned with local economic development. Each of these plans could also be pursued by a university museum or the parent university, and given that university museum 
deaccessions have been among the most problematic cases of reputational damage, an art investment collection could prove to be a more reasonable strategy.

\section{OPTION 1: OUTSIDE ART FUND INVESTMENT}

This first strategy for using art as an investment is simply to have some endowment funds invested in an outside private equity art fund. Two examples are The Fine Art Fund and The Art Trading Fund, both located in London. Although lacking outside verification, according to the firm, the Fine Art Fund $\mathrm{I}^{12}$ had an average profit on its realized assets of $50.99 \%$ in $2006 .{ }^{13}$ The fund was structured as a 10-year closed-end fund, offering capital returns after three years (Kelleher 2006). This type of art investment is useful where a museum does not want to be seen as directly responsible for treating art as an investment, and these funds have a number of advantages, including a diversified pool of artwork, outsourcing of storage, security, insurance and other costs of the works in the art fund portfolio, and a team of experts with experience in the art market and finance.

Compared to the next three plans, the biggest advantage of this plan is that it probably would not engender as much resistance by donors or museum staff who were worried about validating the idea of art as a financial asset, because they would be able to take a hands-off approach, leaving the investment collection decisions with the outside firm. There is also the advantage that this plan could be handled directly by a museum's finance committee or financial advisors, and although this would be a long term investment, depending on the investment terms, this would tend to be a 5 or 10 year holding period as opposed to the longer timeframes suggested above. Additionally, fund-based investment would not require start up costs outside of the investment amounts and due diligence, and would not take time away from museum staff or interfere with their normal duties. The disadvantage of this strategy is that it does not allow 
museums to leverage their existing contacts and expertise to buy artwork at a discount, although it could be possible to pursue a mixed strategy to this end. Moreover, the payouts are typically set at only key time points, such as every three years, or at the end of the full investment period, rather than providing monthly or annual income.

\section{OPTION 2: INTERNAL ART FUNDS MANAGED BY INDEPENDENT ADVISORS}

Compared to the first option, an internal art investment collection would require more involvement and effort for a museum, but could potentially be more profitable. Such a strategy could be implemented using either a collection of works assembled by the museum itself or items chosen on advice by the outside fund and bought by the museum, although only a few firms have been successful enough that they could be considered appropriate for an outside art investment role, such as The Fine Art Fund and The Art Trading Fund.

Once a museum takes an active role in the collection, however, there are increased conflict of interest issues, taxation and moral concerns over the validation of art as an investment. Such an investment portfolio could be taxed under endowment rules, in which case the institution might legally be required to store the works as opposed to displaying them in the museum, or the portfolio could be considered as a related business and taxed accordingly. Conflict of interest issues could arise if trustees recommended the works of artists they owned, which could increase in price if the museum bought these works even for the investment collection.

OPTION 3: SELF-MANAGED INVESTMENT COLLECTION - DONATIONS WELCOME A third strategy for an investment collection has been suggested by some researchers as a way for museums to profit through actively buying and selling artwork. One key example of such a 
strategy is given by O’Hare and Feld in their short piece on investment collections, where they propose that 1) museums set aside a portion of the endowment for investment in works of art; 2) objects are bought for the purpose of future appreciation and sold when other objects promise better financial gain; 3) the investment collection is held separately from the permanent collection; 4) such a collection must offer better returns than securities, once taxes are factored in; 5) objects from the investment collection may be bought for the permanent collection; and 6) the museum would regularly provide public disclosure about the art investment, as well as disclosure of investment interest prior to the purchase of objects $(1975,50)$.

This strategy potentially offers higher financial returns on artwork compared to the first two options because there is no middleman, but the risks and time costs of such a plan could also be high. In particular, curators may resent spending their time finding or valuing works in the investment collection. Furthermore, my research on art investment funds suggests that maintaining an investment collection requires a high degree of sophistication in not just the art market, but strong expertise in both art and finance to be successful. For this reason, a variant of this type of plan, a donation-based investment collection, may be more attractive.

A donation-based investment collection could be very interesting for museum donors and board members, because it would be set up to allow donations of lower quality works like prints and limited editions to a money-raising art collection for the museum. ${ }^{14}$ Many collectors have smaller, lower priced, and less significant works in their collections, particularly from their early days spent collecting, and may welcome the chance to use these to benefit their favorite museum. These works are not likely to be of enough historical significance for museums to include in a permanent collection, but there would also be high transaction costs should collectors want to sell these works themselves. As transaction costs could run to $20 \%$ at auction or even higher 
through a gallery, it would be a welcome measure for collectors to be able to donate these works, and thus receive a tax write off. These artworks could then be included in the investment collection, sold off in special auctions or fundraisers, and perhaps some works could even go into inventory for the museum stores.

There are various advantages to such a plan. Even if museums simply sell artwork from this collection, they are likely to be able to negotiate lower premiums with the auction houses. Moreover, as opposed to the discussion of endowments in the beginning of the paper, where stock market declines can cause donated monies to be locked up against use in times of need, there are different financial regulations about holding physical assets like gold or artwork. However, as this is a very new idea, the tax implications of these various actions are unclear, and museums should be very transparent to collectors that these donations are to be used for revenue generation, as opposed to placement in the permanent collection.

\section{OPTION 4: YOUNG ARTIST DEVELOPMENT FUND}

While an active internal investment collection could be profitable, but also create risks or additional costs for museums, there is another strategy that could justify those risks in terms of the added social benefit. This would be to develop young and emerging artists in a fund, which could be considered to be in line with the mission of some museums to provide opportunities for local artists. This strategy balances the dual nature of artwork with a consideration that young artists will benefit from institutional support, recognizing that museums are well positioned to give this type of support, and already do so by holding special exhibitions by young artists.

The primary examples of this type of art fund are V $22^{15}$ and the Artist Pension Trust, ${ }^{16}$ the artist-managed funds. As described by Siti Osman, "V22 and APT plan to hasten the validation process through promotional activities like exhibitions, website presence, loaning and 
publishing the artists' works during the duration of the holding period.” This would increase the visibility and exposure of these artists, which would also help to build up their provenance, eventually, increasing market confidence in these artists and their works. "The main objective is to increase the value of the artworks over time. However, it remains to be seen to what extent this tactic would generate positive validation by the art market experts” (Osman 2006, 39-40). ${ }^{17}$

A similar strategy is also being used by the World Bank Art Buying Program, where artworks by artists in developing member and client nations are purchased in order to further economic development and cultural investment goals. Given that many of these countries lack a cultural infrastructure and institutions, the World Bank's presence has a strong signaling effect, and there are many success stories of artists who have work in the collection and are then able to enter the major international art market. According to Marina Galvani, Head of the Art Buying Program, using the name of the World Bank does allow artists to develop further, with success stories like an Eritrean artist who came to the U.S. and was able to seek asylum, as well as a Senegalese artist who was able to gain the attention of a curator from the Musée du Paris, who helped him to gain a solo show in Paris, and then thrive back in Senegal. This also creates an important CV item for the artist, which could then allow them to access grants (Galvani 2009). This suggests that the signaling effects of institutional validation are indeed possible, despite the fact that this is yet to be proven in the APT and V-22 plans.

For a museum to take a similar strategy, the institution could actively teach the artists about the workings of the art market, but even if works are just bought for the collection, this would create important CV items, potentially allow artists to access grants, improve the chances of their works going up in value, and perhaps allow these artists to enter into the national or international art markets. 


\section{Conclusion}

This article explored an ongoing and fundamental conflict in views about the financial investment value of artwork—particularly artwork in public collections—and suggested that this conflict is to blame for the sharp outcry over recent museum deaccessions to fund operating costs. This is also an ongoing conflict being played out between museum boards, curators, and other stakeholders, suggesting that direct action to think about the status of artwork in permanent collections should be of prime concern. The cases of deaccession controversies suggest that improper deaccessioning could certainly cause reputational damages or otherwise harm the institutions in question, due to the media frenzy that usually results from such incidents. These cases also suggest that universities are also unwise to view their museum collections as financial assets, because of the public outcry and alienating of past and future donors, not just to the museum, but also to the university.

To address this problem, museum directors, board members, and other stakeholders should have a more detailed discussion about the possible advantages and disadvantages of treating artwork as a financial asset. In particular, an investment portfolio is one way to treat art as a financial asset that would not necessarily entail the same types of tradeoffs between stakeholder trust and financial returns as those caused by deaccessions from the permanent collection. Although this is a longer-term strategy that would not bring in revenue the way the immediate sale of a painting could, these strategies are also more compatible with preserving good will and trust in the institution among stakeholders like donors, trustees and the museumgoing public. This is one way to move along this important discussion in a way that could lead to reconciliation of these divergent views, as opposed to an ongoing and unresolved conflict. The discussion of each of these plans outlined strategies to implement an investment collection, with 
advice about tax implications, accountability and other details. While not all museums would necessarily want to take on this task, implementation of art investment by a few key museums could take on a signaling effect and help to fan this discussion out through the wider community. It is hoped that this would actively engage board members who hold the "art as an investment" view and highlight ways that art could be treated as an investment that would be viewed positively by other museum stakeholders. 


\section{Appendix: Research Methods}

My research on the art market and use of art as an investment used a multi-sited ethnography approach (Marcus 1995) with fieldwork in New York and London, primary centers for both the art market and financial markets. Data sources included 32 interviews with members of the art world and art investment community, including an art fund representative, a museum director, an art consultant, artists, gallerists and others. These interviews used semi-structured interview questions that changed with the role of the interviewee and changed as the project progressed. Approximately half of these interviews were formal, pre-planned interviews lasting approximately one hour or more, and the other half of the interviews were opportunistic interviews at prominent international art fairs. The artists and gallerist interviews primarily came from this category. In addition to the interview, I conducted participant observation at fine art auctions, international art fairs, and attended several panel sessions put together by the Art Dealer's Association of America in New York.

\section{Glossary of Abbreviations}

AAM - American Association of Museums

AAMD - American Association of Museum Directors

BRPF - British Rail Pension Fund 


\section{REFERENCES}

Adeane, Susan, Group Company Secretary for the Railways Pension Trustee Company (RPTCL), 2008. Adeane was one of the four directors of the former British Rail Pension Fund's art investment board during the last 10 years of its existence. Personal interview by the author, London, April 8.

Baram, Marcus. 2005. 'Art funds' starved for investors. The Wall Street Journal.

Blake, David. 2003. Pension Schemes and Pension Funds in the United Kingdom. Oxford: Oxford University Press.

Boehm, Mike. 2009. Getty Trust to Slash Budget as Investments Tumble. The LA Times, March 16.

Campbell, Rachel A. 2008. Art as a Financial Investment. Journal of Alternative Investments 10(4).

Candela, G., and A. E. Scorcu. 1997. A Price Index for Art Market Auctions. Journal of Cultural Economics 21(3):175-196.

Capgemini, and Merrill-Lynch. 2008. The World Wealth Report. New York: Capgemini and Merrill-Lynch.

Chancellor, Edward. 2000. Devil Take the Hindmost: A History of Financial Speculation. New York: Plume.

Finkel, Jori. 2008. Whose Rules Are These, Anyway? The New York Times, December 24.

Gallagher, James. 2009. NCSU, Museum of Art Among Many Facing Endowment Dilemma. Triangle Business Journal, January 9.

Galvani, Marina, Head of the World Bank Art Buying Program, 2009. Phone interview with author, June 17.

Gerlis, Melanie. 2008. Can you trade your way through a recession? The Art Newspaper, April 17.

Houghton, James R. , Economic Letter from the Chairman of the Board of Trustees, 2009. New York, The Metropolitan Museum of Art, February.

Im, Jeongae 2006. Corporate Art Collection as Investment: Mutual Benefits for the Art Markets and the Corporation (Master's of Art Business Thesis). London: Sotheby's Institute of Art.

Johnson, Paddy. 2009. Rose Art Museum's Meryl Rose Speaks Out Against Brandeis Claims. Art in America, April 23, Online Edition.

Katzman, Laura R., and Karol A. Lawson. 2009. The (Im)permanent Collection: Lessons From a Deaccession. Museum News January/February.

Kelleher, Ellen. 2006. 'Sippable' is now the word for more than just fine wines. The Financial Times, July 29/30.

Kidd, Dustin. 2009. Democratic Practices in Arts Organizations. Journal of Arts Management, Law \& Society 38(4):296-309.

Kolter, Neil G., Philip Kolter, and Wendy I. Kolter. 2008. Museum Marketing and Strategy: Designing Missions, Building Audiences, Generating Revenue and Resources. San Francisco: Jossey-Bass.

Marcus, George. 1995. Ethnography in/of the World System: The Emergence of Multi-Sited Ethnography. Ethnography Through Thick and Thin, Princeton: Princeton University Press.

McAndrew, Clare. 2007. The Art Economy: An Investor's Guide to the Art Market. Dublin: Liffey Press. 
Merritt, Elizabeth E. (Ed.). 2006. 2006 Museum Financial Information. Washington, DC: American Association of Museums.

Mok, Henry M. K., Vivian W. K. Ko, Salina S. M. Woo, and Katherina Y. S. Kwok. 1993. Modern Chinese paintings: an investment alternative? Southern Economic Journal:80816.

O'Hare, Michael. 2005. Capitalizing Art Museum Collections: Awkward for Museums But Good for Art and for Society. Paper Presented at the Association for Public Policy Analysis and Management Research Conference. Washington DC.

O'Hare, Michael, and Alan L. Feld. 1975. Is Museum Speculation in Art Immoral, Illegal and Insufficiently Fattening? Museum News May:24-26, 52.

Osman, Siti. 2006. Artists Investing in Themselves: A Recipe for Success or Destruction? (Unpublished Master of Art Business Thesis). London: Sotheby's Institute of Art.

Panero, James. 2009. Another Art Museum Puts Its Collection on the Block. The Wall Street Journal, April 15, D13.

Reif, Rita. 1989. Auctions. The New York Times, December 22.

Robertson, Iain. 2005. The Current and Future Value of Art. Understanding International Art Markets and Management, ed. by Iain Robertson, 228-59. London: Routledge.

Trucco, Terry. 1989. British Pension Fund Sells \$65.6 Million in Artworks. The New York Times, April 5.

Velthuis, Olav. 2003. Symbolic Meanings of Prices: Constructing the Value of Contemporary Art in Amsterdam and New York Galleries. Theory and Society 32:181-215.

—. 2005. Talking Prices: Symbolic Meanings of Prices on the Market for Contemporary Art. Princeton: Princeton University Press.

Watson, Peter. 1992. From Manet to Manhattan: The Rise of the Modern Art Market. New York: Random House.

Wee, Gillian, and Janet Frankston Lorin. 2009. Brandeis to Close Rose Art Museum as Endowment Slips (Update1). Bloomberg.com, January 27.

Willette, Randall, CEO and Founder, Fine Art Wealth Management, London, an art advisory firm, 2009. Phone interview by author, January 20.

Zaretsky, Donn. 2009. Opinion: AAMD Rules Need to be Deaccessioned. Art in America 97(4):28.

Zelizer, Viviana. 1983. Morals and Markets: The Development of Life Insurance in the United States. New Brunswick: Transaction Books.

—. 2000. The Purchase of Intimacy. Law and Social Inquiry 25(3):817-848. 


\section{TABLES}

TABLE 1: Museum Funding Sources, 1989-2005

\begin{tabular}{|l|l|l|l|l|}
\hline & Government & Private & Earned & Investment \\
\hline Overall 1989 & $39.2 \%$ & $18.9 \%$ & $30.4 \%$ & $11.5 \%$ \\
\hline 1996 & 29.6 & 22.8 & 34.4 & 13.0 \\
\hline 1997 & 30.9 & 24.5 & 33.2 & 11.5 \\
\hline 1999 & 27.9 & 32.3 & 28.6 & 11.3 \\
\hline 2002 & 25.4 & 34.7 & 29.8 & 10.6 \\
\hline 2005 & 24.1 & 35.2 & 31.0 & 9.6 \\
\hline
\end{tabular}

Source: Merritt (2006); Also in Kolter, Kolter \& Kolter (2008, 191)

(These figures are compiled from a variety of museums: art, science, and historical.) 


\section{NOTES}

${ }^{1}$ Deaccessions are deacquisitions of artwork from the permanent collections, usually through sale, and occasionally through donations.

${ }^{2}$ I will focus on the case of U.S. museums in this paper, given that U.S. tax law has a strong impact on museum finance strategies and American museums often enjoy much lower public funding than their European counterparts. Nevertheless, I hope my findings can productively inform finance strategy for museums outside of the U.S. My focus on museums in this article is primarily art museums, although there have been some cases of science museums facing similar pressures about deaccessioning items and selling them to finance operating costs.

${ }^{3}$ Not all museums are members of both or one organization; membership has useful benefits such as lower costs for lending works from other member institutions.

${ }^{4}$ This idea has been suggested by others, eg. O’Hare and Feld (1975), but to my knowledge, has never been taken up by a U.S. museum, although there have been many cases where museums sold works to finance operating costs.

${ }^{5}$ It probably does not help that corporate art collections, which are managed in a curatorial fashion and are sometimes donated to museums or universities, tend to be sold off in hard times by the business, thus reinforcing the view that while ideally, an organization should keep artwork for cultural values, it can capitalize upon it in hard times, as was the case with the Lehman Brother's collection. See also Im (2006).

${ }^{6}$ This is a state-level law, so the point at which endowments are locked up varies between states.

${ }^{7}$ Art gallerists also have another pragmatic concern, particularly for contemporary art, which is that treating it as a financial investment can disrupt the long-term processes of value construction (Velthuis 2005).

${ }^{8}$ This roughly corresponds to the "nothing but" view of markets vs. aesthetic or sacred objects, as opposed to the "hostile worlds" view, where money harms or trivializes the meaning of art, or the sacred objects. For more on this topic, see Zelizer (1983; 2000) for a more general discussion, and Velthuis (2003; 2005) for a discussion of art specifically.

${ }^{9}$ One point of evidence for this is that artwork is mentioned by the Capgemini World Wealth Report under the category of "passion investments" (e.g. Capgemini and Merrill-Lynch 2008, 21-2).

${ }^{10}$ Non-member institutions, however, could still be harmed from the ethical guidelines if they deaccessioned work, in the form of sanctions like not being allowed to borrow works from member institutions, which could harm their ability to put together special exhibitions. Image problems could also be part of the consequences.

${ }^{11}$ For example, a T'ang horse sculpture was stolen from a shipper's warehouse in Hong Kong by the Triads just before it was supposed to be shipped back to London for sale. BRPF worked with the Hong Kong police to successfully recover the piece, according to Adeane, which was sold in London for \$5.9 million (1989 dollars) (Reif 1989).

${ }^{12}$ Art funds are typically conducted in various tranches of investment offered by the management firm. The Fine Art Fund I refers to the first investment tranche offered by the fund.

${ }^{13}$ Promotional Flyer, “The Fine Art Fund II” Fine Art Management Services, Ltd. 2006.

${ }^{14}$ This plan was helpfully suggested by Peter Frumkin of the RGK Center for Philanthropy at University of Texas, Austin, who would love to be able to donate some of his editioned work to financially benefit a museum.

${ }^{15}$ http://www.v22london.com

${ }_{10}^{16}$ http://www.artistpensiontrust.org

${ }^{17}$ I should note that while this type of insider connection is illegal in financial security markets under the category of insider trading, there is no such regulation in the art market. 